\title{
Increased serum lysozyme activity in children with autism spectrum disorder
}

\author{
Nola Montiel ${ }^{1,2,3}$, Milagros Escalona ${ }^{4}$, Yenddy Carrero ${ }^{1,5}$, Kendy Eduardo Urdaneta ${ }^{1,2,3}$, \\ María Andrea Castillo ${ }^{1,2,3}$, Dilia Martínez-Ménde: ${ }^{1}$ and Neomar Semprún-Hernándes ${ }^{1,2,3}$. \\ ${ }^{1}$ Laboratorio de Métodos Inmunológicos, Departamento de Biología, Facultad \\ Experimental de Ciencias, Universidad del Zulia, Maracaibo, Venezuela. \\ ${ }^{2}$ Cátedra Libre de Autismo. Vicerrectorado Académico, Universidad del Zulia, \\ Maracaibo, Venezuela. \\ ${ }^{3}$ División de Investigaación, Unidad Inmunología del Autismo (UIANM), Maracaibo, \\ Venezuela. \\ ${ }^{4}$ Facultad de Ciencias de la Salud, Universidad Técnica de Ambato, Ecuador. \\ ${ }^{5}$ Laboratorio de Biología Celular y Molecular, Carrera de Medicina, Facultad de Ciencias \\ de la Salud, Universidad Técnica de Ambato, Ecuador.
}

Key words: phagocytosis; neutrophils; lysozyme; autism; ASD.

Abstract. Recent studies have suggested that Autism Spectrum Disorder (ASD) may be caused by immunological factors, particularly, abnormalities in the innate immune system. Polymorphonuclear neutrophils (PMNs) play a critical role in host defense against infection and in the resolution of inflammation, hence lysozyme plays an important role in the innate immune system. The aim of this study was to determine the in vitro phagocytic and lysozyme activity in individuals with ASD, by biochemical and immunological techniques. Results indicate that there are no qualitative or quantitative differences in the in vitro phagocytic activity between ASD and typical development (TD) subjects. The ability to reduce Nitro Blue Tetrazolium by PMNs was compared and there were no significant differences between groups. The percentage of yeasts eliminated by phagocytosis at 20 minutes of exposure to PMNs, was lower in ASD children compared to TD children; however, no significant differences were observed between the percentages of cells eliminated after 5 and 20 minutes of treatment in both populations $(\mathrm{p}>0.05)$. Serum lysozyme basal levels were greater in children with ASD probably due to a compensatory state because of the immunological deregulation reported for this neurodevelopmental disorder.

Corresponding author: Neomar Semprún-Hernández, Laboratorio de Métodos Inmunológicos, Departamento de Biología, Facultad Experimental de Ciencias, Universidad del Zulia, Maracaibo, Venezuela. Email: neomar.semprun@gmail.com. Phone:+58 4146209282 


\title{
Incremento de la actividad de la lisozima sérica en niños con trastornos del espectro autista
}

\author{
Invest Clin 2018; 59 (3): 250 - 259
}

Palabras clave: fagocitosis; neutrófilos; lisozima; autismo; TEA.

Resumen. Estudios recientes han sugerido que la etiología de los Trastorno del Espectro Autista (TEA) puede ser causada por factores inmunológicos, particularmente anormalidades en el sistema inmunitario innato. Los neutrófilos polimorfonucleares (PMNs) juegan un papel crítico en la defensa del huésped contra la infección y en la resolución de la inflamación, así como la lisozima jueǵa un papel importante en la inmunidad innata. El objetivo de este estudio fue determinar la actividad fagocítica y la lisozima in vitro de individuos con TEA, mediante técnicas bioquímicas e inmunológicas. Los resultados indican que no hay diferencias cuali-cuantitativas en la actividad fagocítica in vitro entre individuos con TEA y sujetos con desarrollo típico (DT). Se comparó la capacidad de reducir nitroazul de tetrazolio por PMNs y no hubo diferencias significativas entre los grupos. El porcentaje de levaduras eliminadas por fagocitosis a los 20 minutos de exposición a los PMNs fue menor en los niños con TEA en comparación con los niños con DT; sin embarǵo, no se observaron diferencias significativas entre los porcentajes de células eliminadas después de 5 y 20 minutos de tratamiento en ambas poblaciones ( $p>0,05)$. Los niveles basales de lisozima sérica fueron mayores en niños con TEA probablemente debido a un estado compensatorio como consecuencia de la desregulación inmunológica reportada para este trastorno del neurodesarrollo.

Recibido: 23-01-2018 Aceptado: 01-08-2018

\section{INTRODUCTION}

Autism spectrum disorder (ASD) comprises a series of neurodevelopmental disorders characterized by stereotyped behaviors, language deficits, communication and social interaction difficulties (1). The incidence of ASD has increased until reaching in $2014,14.7$ cases per 1,000 children, 1 by every 68, only in the United States (2). The pathophysiology of ASD involves genetic, environmental, metabolic, neurological and immune processes. The alteration of most components of the immune system has been described, including the decrease of cellular subpopulations, alteration in the cytokines mediated patterns and deviation in the immunoglobulins (Igs) functioning, favoring the development of autoimmunity, immunodeficiency and allergy. $(3,4)$. In the last decades the studies seek to understand the molecular interdependence between the immune and the nervous system as the main ethiopathology of ASD; however, this interaction, linked to the central nervous system and considered as a type of "cerebral allergy", is controversial (5).

As part of the innate immune response, phagocytosis is an effective mechanism of host defense against microorganisms. This function is made by two main categories of phagocytic cells: the polymorphonucle-

Vol. 59(3): $250-259,2018$ 
ar cells (PMN) and the mononuclear cells $(\mathrm{MN})$, both originate in the bone marrow and are formed by cells that circulate in the blood or are fixed in the tissues and migrate to sites of inflammation where they do their function (6). The dysfunction of cellular and humoral elements mediating the immune response, justify the interest and the need to carry out studies to evaluate the phagocytic and serum lysozyme activities as part of the non-specific defense immune mechanisms. Lysozyme activity and phagocytosis in children with ASD have not been clarified to this date. A few studies have shown the microglia role in phagocytosis and structural remodeling of brain development (7), but no research has been carried out to study systemic phagocytosis in which the humoral response might act as a risk factor predisposing children with ASD to infectious diseases.

\section{PATIENTS AND METHODS}

\section{Participants and enrollment criteria}

Participants were recruited from Zulia State (Venezuela) with the autism foundation. The study population consisted of 66 individuals, 33 with ASD, diagnosed under the Diagnostic and Statistical Manual of Mental Disorders (DSM-V) criteria and 33 neurotypical (TD) subjects in pediatric ages (ASD: $7.91 \pm 3.4$ years and TD: $7.8 \pm 4.4$ years), all of the subjects were male and $17 / 33$ of them were diagnosed with High Functioning Autism (HFA). The participants were divided into two groups: a) ASD group: individuals diagnosed with ASD, b) Unrelated control group: individuals with neurotypical development (TD) without diagnosis of ASD. Individuals who had received anti-inflammatory treatment such as: NSAIDs and steroids three months prior to taking the sample and who suffers from any immunological disease (Primary immunodeficiency diseases, infantile autoimmunity or hypersensitivity reactions) were excluded from the study, even those who presented some psychological, psychiatric or other medical disease.

\section{Study protocol}

Individuals were selected and enrolled in the study following a stratified sampling of the population. The approval of the bioethics committee associated with the Autism Free Chair was carried out following the delineation of the Helsinki Declaration of 1975 revised in 2008. The study was explained to the participants and informed parent/child consent was acquired. Five milliliters of blood were obtained from each participant by venipuncture conventional method with and without anticoagulant (EDTA). The samples with anticoagulant were used for the extraction of mononuclear cells by the density gradient technique with Histopaque ${ }^{\circledR}-1077$ (SigmaAldrich, Darmstadt, Germany) with the purpose of separating the neutrophils PMNs. The samples collected without anticoagulant were kept at $37^{\circ} \mathrm{C}$ for 1 hour, allowing retraction of the clot and subsequent collection of the serum by centrifuging at $2000 \mathrm{rpm}$ for 10 minutes. Serum samples were aliquoted and stored in the refrigerator at $-20^{\circ} \mathrm{C}$ until processing.

\section{Measurement of in vitro phagocytic and lysozyme activity}

Three tests were carried out, the first one related to the measurement of in vitro lysozyme activity in basal serum through the Lysozyme Plate Lysis Assay according to the Mock and Peters (8) technique. The second test was related to the indirect measurement of in vitro phagocytic activity through the Nitro Blue Tetrazolium Reduction (NBT) procedure (9). This procedure measures the in vitro phagocytic activity by determining if the cells are able to reducing NBT from its oxidized form of yellow to a blue-purple color, becoming cells easily recognizable by the formation of formazan crystals. Finally, the cells that had the blue-stained cytoplasm were quantified in relation to a hundred total the cells that had the blue-stained cytoplasm were quantified in relation to a hundred total cells. The third one was the Plate Dilution Technique as a phagocytic 
test, which consists in separating the sediment that contained neutrophils from gradient separation tube by Histopaque ${ }^{\circledR}-1077$ (Siǵma-Aldrich, Darmstadt, Germany). Red blood cell lysis was performed, to purify the granulocytes with ammonium chloride, then centrifuged at $1500 \mathrm{rpm}$ for 10 minutes at $4^{\circ} \mathrm{C}$ and the supernatant was discarded; the cellular cue was resuspended by adding 3.5\% $\mathrm{NaCl}$; it was centrifuged again at $1500 \mathrm{rpm}$ for $10 \mathrm{~min}$ at $4^{\circ} \mathrm{C}$, and the cells were resuspended in phosphate-buffered saline (PBS); it was centrifuged and the cells were maintained in PBS until its quantification.

A culture of the microbial specie Candida albicans ATCC 18804 standardized for $10^{6}$ viable yeasts / $10 \mu \mathrm{L}$ was used, from its growth curve (this density was obtained at 18 hours of eulture in tubes containing heart brain infusion). Cell counting was performed in a hematimeter chamber, using trypan blue dye, to measure viability, cell density was adjusted to $10^{6}$ neutrophils PMNs/mL with autologous plasma. Then, neutrophil PMN suspension was mixed with the culture of C. albicans ATCC 18804 (ratio 1: 1) and incubated at $37^{\circ} \mathrm{C}$. Aliquots of each mixture were extracted at $5 \mathrm{~min}$ and at $20 \mathrm{~min}$, performing serial dilutions, previously standardized, in order to obtain an optimal number of viable cells for the colony count (dilutions $10^{-1}$ y $10^{-2}$ ). It was established as initial time ( 0 min of exposure) to a group of tubes (controls) containing the yeast culture without PMN neutrophils (only autologous plasma), processed immediately after adding $C$. albicans. One hundred $\mu \mathrm{L}$ of each dilution and at each incubation time were subsequently cultured on plates with Sabouraud dextrose agar (SDA), uniformly distributing the inoculum with a Drigalski spatula. These plates were incubated at $37^{\circ} \mathrm{C}$ for 24 hours, and finally proceeded to count colonies (viable yeasts). The percentage of phagocytosed cells was calculated from the difference between the viable yeasts in each plate for the corresponding exposure time
(5 and $20 \mathrm{~min}$ ) and the amount of yeasts present at time zero.

Lysozyme Plate Lysis Assay measures lysis halos on the agar plates containing the microorganism whose cell wall is susceptible to the hydrolytic action of the enzyme. A culture of the microbial specie Micrococcus lysodeikticus in each plate were placed eight samples: three constituted by standard solutions (dilutions of chicken lysozyme $10^{-1}, 10^{-2}$ and $10^{-3}$, obtained from a stock solution at $1 \%$, equivalent to 462,000 Units of lysozyme / $\mathrm{mL}$ ) and five samples belonging to the serum of patients and/or healthy children. All the tests were performed in duplicate. The plates were then taken to the oven at $37^{\circ} \mathrm{C}$ for $16-18$ hours. Finally, diameters (mm) of the lysis halos formed on the plates were measured; the lysozyme values in the serum samples of children with ASD and of TD children were extrapolated from a calibration graph made with the different dilutions of the lysozyme standard, versus the diameters of the lysis halos.

Statistical Analysis. The SPSS Software v.24 was used depending on the types of data obtained. The data were analyzed by running the Student's " $t$ " test, in order to establish differences between the control and pathological groups, considered significant when the value of $\mathrm{p}<0.05$.

\section{RESULTS}

In the study of the function of phagocytic cells, through the NBT technique, the results obtained allowed us to indicate, both in children with ASD and in children TD, that all the cells evaluated, mainly from the granulocytic serie, were able to reduce the nitro blue tetrazolium dye, the amount of cells whose cytoplasm presented formazan crystals were quantified in relation to hundred cells (Fig. 1); this shows that children with ASD cells expressed the characteristic respiratory burst, $100 \%$ of the ASD and TD children cells were positive to the NBT reduction, likewise, taking into account the results obtained and

Vol. 59(3): 250 - 259, 2018 
the basis of the technique used, granulocytes of children with ASD spontaneously showed phagocytic activity.

Plate dilution technique assessed the percentage of yeasts eliminated by phagocytosis at 20 minutes of exposure to neutrophils PMNs was lower in ASD children compared to healthy children (Table I); however, no significant differences were observed between the percentages of eliminated cells at 5 and 20 minutes (Fig. 2), in the two populations evaluated $(\mathrm{p}>0.05)$. Notwithstanding, there was apparently a tendency to increase the pereentage of eliminated yeasts (microbicidal activity) in the TD children compared with the ASD children (Fig. 3). Both groups were very heterogeneous in terms of the average values obtained, with coefficients of variation $>50 \%$, due to the differences observed in the percentages of phagocytosis and elimination of $C$. albicans for each group.

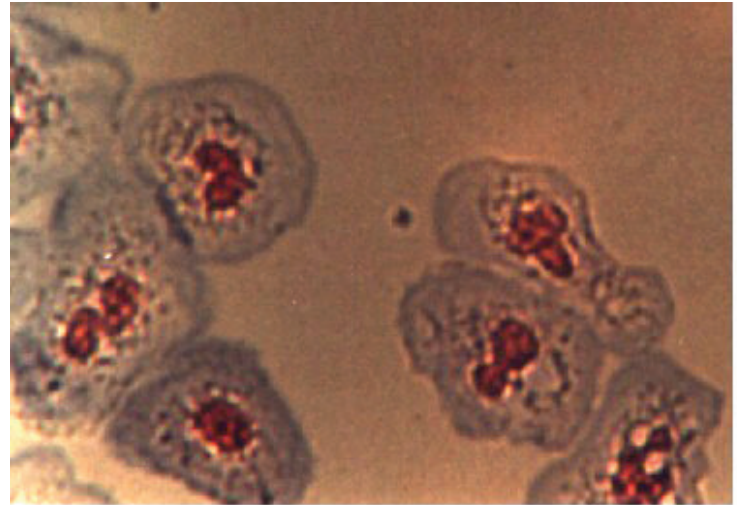

(a)
Lysozyme plate lysis assay assessed lysozyme activity, this was detected and quantified by the plate lysis method upon the Micrococcus lisodeitikus (Fig. 4). In this study, the lytic activity of serum lysozyme was determined at $\mathrm{pH} 6$, at which in previous stages of this investigation it was shown to have the highest activity in patients evaluated (data not included). The test shows the susceptibility of the bacterial wall by the hydrolytic action of the enzyme evidenced by the appearance of lysis halos on the plates of agar containing the microorganism. The serum lysozyme levels were significantly higher in children with ASD (55.94 \pm 25.66 Units/ $\mathrm{mL})$ compared to the TD children $(31.79 \pm$ 16.61 Units/mL) $(p<0.0000001)$ (Fig. 5), coefficients of variation of the samples of children with autism and TD children were $45.87 \%$ and $52.27 \%$, respectively.

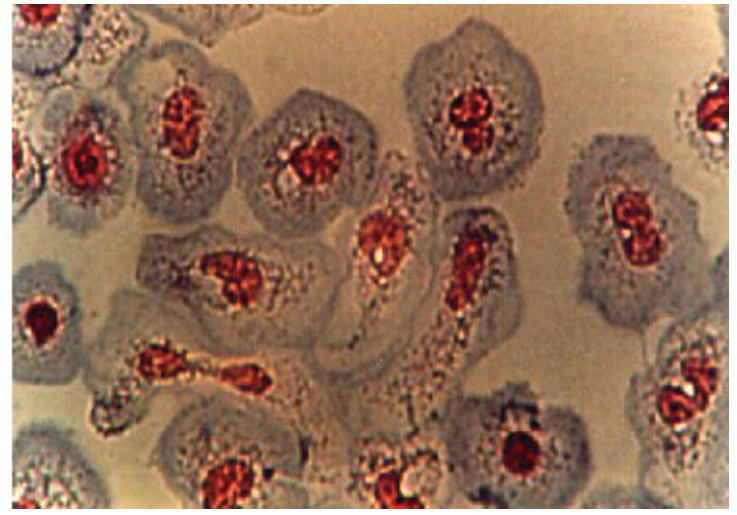

(b)

Fig. 1. Phagocytic cells treated with tetrazolium nitro blue dye (NBT). (a) Children with ASD. (b) TD Children. 1000X.

TABLE I

EVALUATION OF PHAGOCYTIC AND MICROBICIDAL CAPACITY OF NEUTROPHIL POLYMORPHONUCLEAR LEUKOCYTES AGAINST Candida albicans

\begin{tabular}{ccc} 
& Exposure Time (min) & Eliminated yeasts (\%) \\
\hline Children with ASD & 5 & $26.78 \pm 24.21$ \\
$(n=33)$ & 20 & $30.31 \pm 15.51$ \\
TD Children & 5 & $23.92 \pm 23.38$ \\
$(n=33)$ & 20 & $42.87 \pm 22.39$ \\
\hline
\end{tabular}



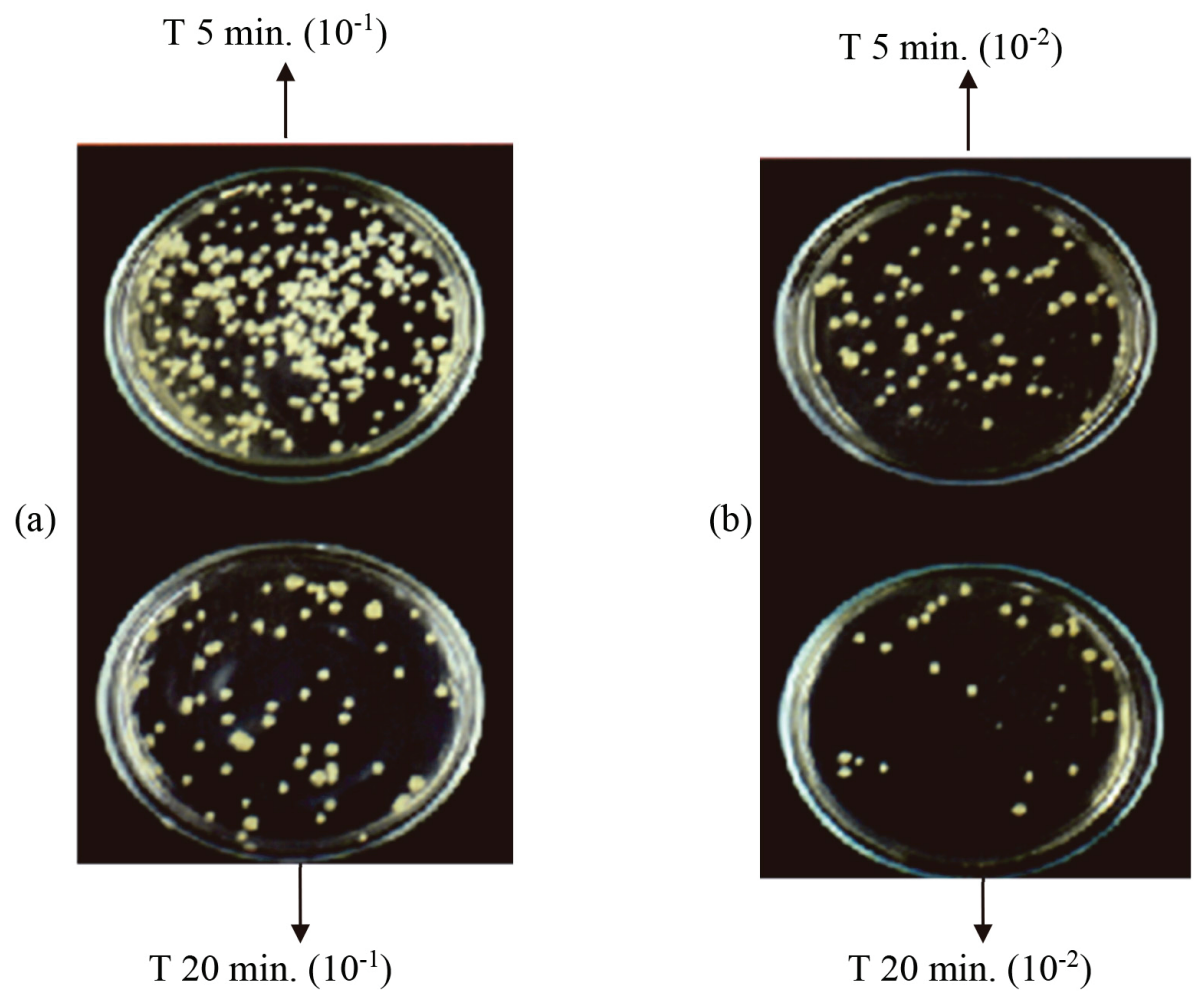

Fig. 2. Colonies of Candida albicans in Sabouraud dextrose agar plates, after exposure (5 and 20 minutes) to polymorphonuclear neutrophils isolated from children with ASD (a) and TD children (b).

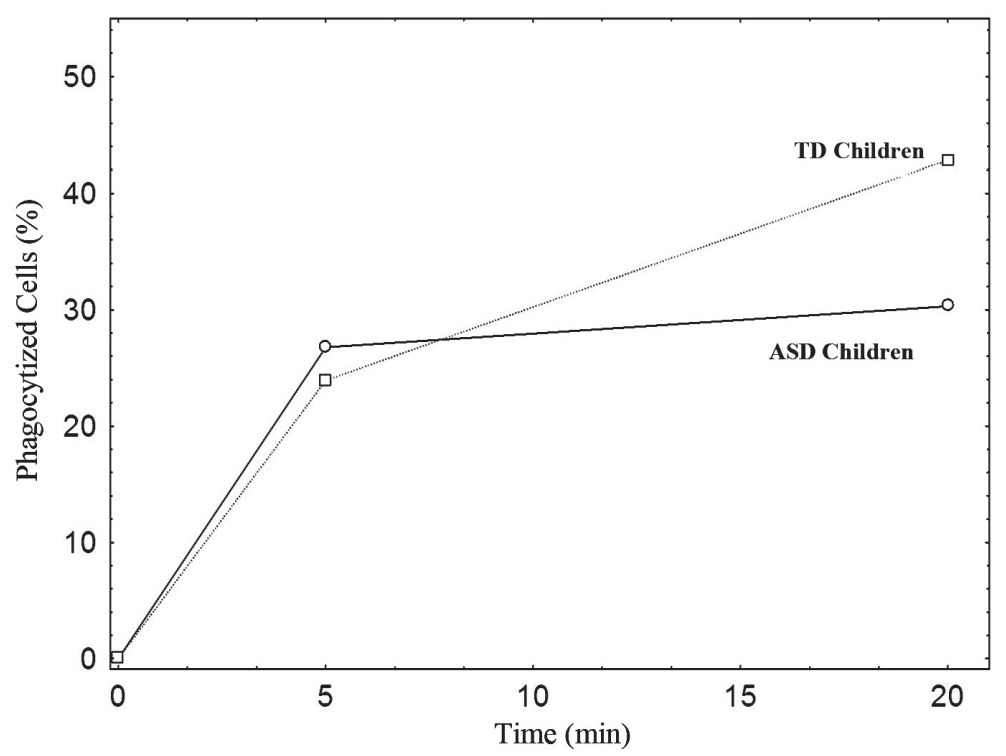

Fig. 3. Representation of phagocytic and microbicidal capacity of polymorphonuclear neutrophil leukocytes against the yeast Candida albicans, in children with ASD vs TD children. 


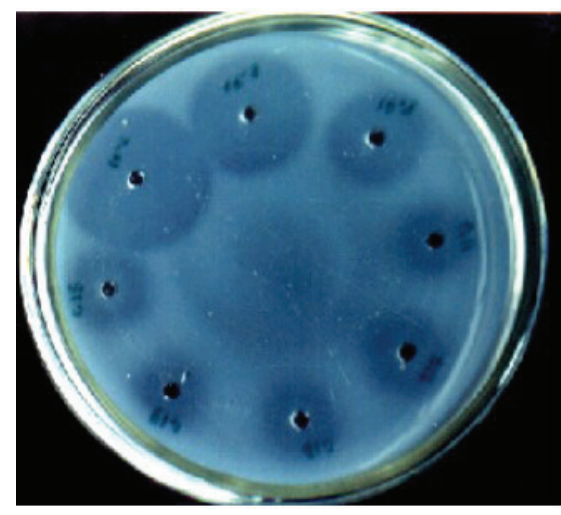

(a)

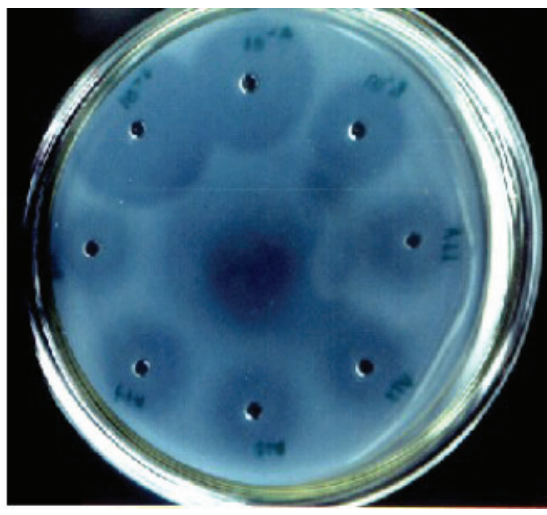

(b)

Fig. 4. Lysis halos on agar plates containing Micrococcus lysodeikticus. (a) TD children (b) ASD children.

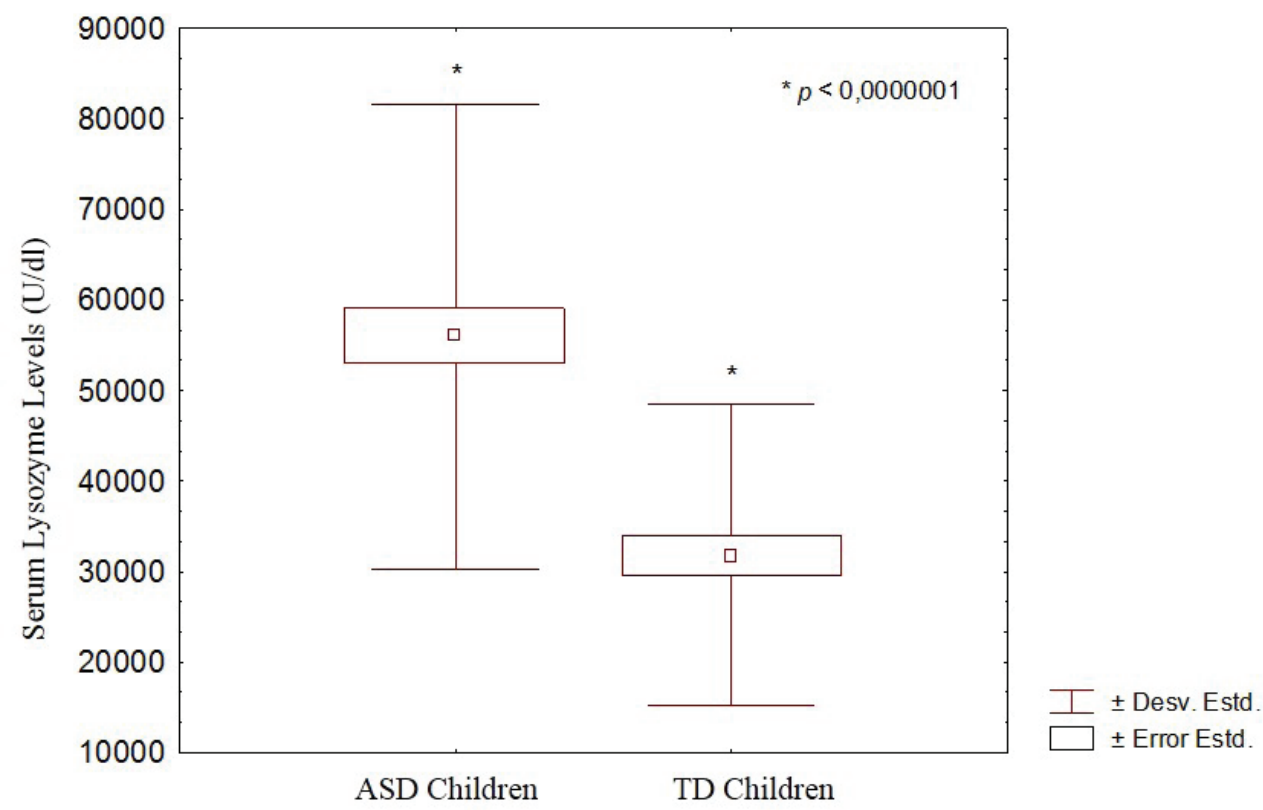

Fig. 5. Basal levels of serum lysozyme in children with ASD and TD children. (" indicates statistically significant differences).

\section{DISCUSSION}

In this research, phagocytic activity and serum lysozyme were evaluated as components of the innate immune response in children with ASD. Previous reports have reported an innate and specific immunity deregulation in these children, involving both humoral and cellular response, which is important because these systems act in con- junction (10-14). The respiratory burst is a mechanism that describes a metabolic pathway in which oxygen consumption occurs abruptly, the function of this is to produce a group of highly reactive intermediates by partial reduction of oxygen. The respiratory burst occurs with the neutrophils PMNs. This is a reversible process that does not require any process of internalization or degranulation (6). 
When these phagocytic cells do not have the capacity to eliminate certain microorganisms, they do not express the respiratory burst and do not reduce the NBT. It should be emphasized that NBT reduction may be due to several factors, despite this, it is commonly used to measure non-enzymatic or oxidative degradation, oxidation-Reduction reactions whose electrons can be captured by the NBT cause the color change of the chromophore and reveal the presence and intensity of the reaction. A typical example of children where this case turns out to be the main defect is the chronic granulomatous disease, in which patients are affected by repeated bacterial infections (15). The percentage of eliminated yeasts by phagocytosis by neutrophils PMNs was lower in ASD children $(26.78 \pm 24.21$ and $30.31 \pm 15.51$ at 5 and $20 \mathrm{~min}$ respectively) compared to TD children $(23.92 \pm 23.38$ and $42.87 \pm$ 22.39 at 5 and 20 min respectively); however, no statistically or physiologically significant differences were observed. Studies in murine models of autism comorbidities demonstrate the phagocytic activity of systemic immune cells is compromised in a Drosophila melanogaster model of X Fragile, highlighting intriguing new mechanistic connections between FMRP (Fragile X Mental Retardation Protein), innate immunity, and abnormal development (16).

The NBT reduction assay has been used to measure the oxidative capacity of phagocytic and non-phagocytic cells (17-21). In the case of phagocyte cells, it is linked to phagocytosis. The reduction of NBT may also be linked to the oxidative basal state of the cell (22) as well as in chronic granulomatous disease, where there is an oxidative metabolism alteration in phagocytes (23). This test can also measure cell adhesion, lysosomal degranulation (24) and even the oxidative capacity of isolated mitochondria (25). The induction of cytokines that modify the oxidative metabolism and the capacity of ROS to induced apoptosis, reduce the number of cells that can yield changes in NBT reduction values (26). When using the NBT reduction test, it would be of interest to study whether the results correspond to the phagocytic capacity or the possible role of the previous described conditions.

The lysozyme, on the other hand, is an endo-acetyl-muraminidase that breaks the bonds between repeating units of $\mathrm{N}$-acetylmuramic acid and $\mathrm{N}$-acetylǵlucosamine in peptidoglycans of the bacterial wall. This important humoral component is an enzyme with antimicrobial activity that is present in elevated levels of the primary and secondary cytoplasmic nuclei of polymorphonuclear cells, neutrophils and those that are least elevated in macrophages. They are also found in lacrimal and salivary fluids, urine, sweat, pancreatic juice and other mucous membranes or organs, where it is produced by specialized secret cells. It can usually cause lysis in grampositive and gram-negative bacteria.

Lysozyme is considered as an indicator of innate immune response and even more, phagocytic activity. This is based on the premise that the phagocytic activity leads to the release of certain granular components into the extracellular environment, and based on the assumption that if phagocytosis is stimulated by the presence of an immunogen, then the amount of lysozyme presents in the affected compartments and in serum blood is increased. However, it is not clear whether the amount of intact lysozyme released by the activated phagocytes is enough to detect an increase in the enzyme beyond the limits of these compartments. It can be inferred that an increase in circulating levels of lysozyme should not be an indicator of increased phagocytic activity. However, recent studies report an altered physiological behavior of lysozyme in children with autism. In the first one it was a study carried out in murine model of autophagy in which Lyz2-Cre mice was owing to dysfunctional synaptic pruning by microglia during early brain development. Microglia have a crucial role in the development of functional brain connectivity by eliminating unneces- 
sary synapses through phagolysosomes during the first three weeks of life. Autophagy in microglia may affect the functional connectivity between brain regions and impairment of microglial autophagy results in reduced functional connectivity and ASD-like behaviors (27). Additionally, stool lysozyme was somewhat lower in children with autism $(27 \%, p=0.04)$, according to the authors of the study, possibly associated with probiotic usage (28). In this study, the basal levels of serum lysozyme in children with ASD are higher, compared to the levels of the enzyme in children TD inferring that this metabolic feature is due to a compensatory state by the immune system because immunological deregulation reported in many defense mechanisms in this type of disorder.

As a conclusion we found that there are no in vitro qualitative and quantitative differences in phagocytic activity measured by the ability to reduce nitro blue tetrazolium and elimination levels of Candida albicans mediated by polymorphonuclear cells between children with ASD and TD children. The basal levels of serum lysozyme in children with ASD are significantly higher, which mean that children with ASD tries to regulate immunological alterations, compensating the humoral with cellular activity and backwards, which is evidenced with the increase of lysozyme basal levels when phagocytic activity of the polymorphonuclear cells is diminished.

\section{REFERENCES}

1. Hsiao E, MeBride S, Hsien S, Sharon G, Hyde E, MeCue T, Codelli J, Chow $\mathbf{J}$, Reisman R, Petrosino J, Patterson P, Mazmanian S. The microbiota modulates gut physiology and behavioral abnormalities associated with autism. Cell 2013; 155(7):1451-1463.

2. Baoi J. Prevalence of autism spectrum disorder among children aged 8 years-autism and developmental disabilities 617 monitoring network, 11 sites, United States, 2010. MMWR Surveill Summ 2014; 63:121.
3. Heuer L, Ashwood P, Schauer J, Goines P, Krakowiak P, Hertz-Picciotto I, Hansen R, Croen L, Pessah I, Van de Water J. Reduced levels of immunoglobulin in children with autism correlates with behavioral symptoms. Autism Research 2008; 1(5):275-283.

4. Enstrom A, Lit L, Onore C,Greǵg J, Hansen R, Pessah I, Hertz-Picciotto I, Van de Water J, Sharp F, Ashwood P. Altered gene expression and function of peripheral blood natural killer cells in children with autism. Brain Behavior Immunology 2009; 23(1): 124-133.

5. Theoharides, T. Is a Subtype of autism an allergy of the brain? Clin Ther 2013; 35(5):584-589.

6. Azcutia V, Parkos CA, Brazil JC. Role of negative regulation of immune signaling pathways in neutrophil function. $J$ Leukoc Biol 2017 Dec 19. doi: 10.1002/ JLB.3MIR0917-374R. [Epub ahead of print]

7. Areuri C, Mecea C, Bianchi R, Giambanco I, Donato R. The pathophysiological role of microglia in dynamic surveillance, phagocytosis and structural remodeling of the developing CNS. Front Mol Neurosei 2017; (10):191.

8. Mock A, Peters G. Lisozyme activity in rainbow trout, Oncorhynchus mykiss, stressed by handling, transport and water pollution. J Fish Biol 1990; 37: 873 -885.

9. Gifford RH, Malawista SE. A simple rapid micromethod for detecting chronic granulomatous disease of childhood. J Lab Clin Med 1970; 75(3):511-519.

10. Sweeten TL, Posey DJ, McDouǵle GJ. High blood monocyte counts and neopterin levels in children with autistic disorder. Am J Psychiatry 2003; 160(9):1691-1693.

11. Xie J, Huang L, Li X, Li H, Zhou Y, Zhu H, Pan T, Kendrick KM, Xu W. Immunological cytokine profiling identifies TNF- $\alpha$ as a key molecule dysregulated in autistic children. Oncotarget 2017; 8(47):82390-82398.

12. Fluegge K. Humoral immunity and autism spectrum disorders. Immunol Lett 2017; 185:90-92.

13. Edmiston E, Ashwood P, Van de Water J. Autoimmunity, autoantibodies, and autism spectrum disorder. Biol Psychiatry 2017; 81(5):383-390.

14. Gładysz D, Krzywdzińska A, Hozyasz KK. Immune abnormalities in autism spectrum 
disorder-Could they hold promise for causative treatment? Mol Neurobiol 2018 Jan 6. doi: 10.1007/s12035-017-0822-x. [Epub ahead of print]

15. Lew PD, Southwick FS. A variant of chronic granulomatous disease: deficient oxidative metabolism due to a low - affinity NADPH - oxidase. N Enǵl J Med 1981; 305: 1329.

16. O'Connor RM, Stone EF, Wayne CR, Marcinkevicius EV, Ulgherait M, Delventhal R, Pantalia MM, Hill VM, Zhou CG, McAllister S, Chen A, Ziegenfuss JS, Grueber WB, Canman JC, Shirasu-Hiza MM. A Drosophila model of Fragile $\mathrm{X}$ syndrome exhibits defects in phagocytic by innate immune cells. J Cell Biol 2017; 6;216(3):595-605.

17. Rainard, P. A colorimetric microassay for opsonins by reduction of NBT in phagocytosing bovine polymorphs. J Immunol Methods 1986; 90: 197-201.

18. Maly FE, Nakamura M, Gauchat JF, Urwyler A, Walker C, Dahinden CA, Cross AR, Jones OT, de Weck AL. Superoxidedependent nitroblue tetrazolium reduction and expression of cytochrome b-245 components by human tonsillar B lymphocytes and B cell lines. J Immunol 1989; 142(4):1260-1267.

19. De Jonge CJ. A clinical assay for reactive oxyǵen species-ready for primetime? Reprod Biomed Online 2018; 36(1):88-89.

20. Kinoshita A, Yamada K, Kohmura E, Hayakawa T. Human recombinant superoxide dismutase protects primary cultured neurons against hypoxic injury. Pathobiology 1991;59(5):340-344.

21. Gosálvez J, Fernández JL, Esteves SC. Response: Nitroblue tetrazolium (NBT) assay. Reprod Biomed Online 2018; 36(1):92-93.
22. Müller J, Alföldy P, Lemmel E-M. Nitrobluetetrazolium test for the functional evaluation of phagocytic cells: A critical analysis of the methodology. Agents Actions 1981; 11(4):384-390.

23. Justiz Vaillant AA, Qurie A. Immunodeficiency. StatPearls [Internet]. Treasure Island (FL): StatPearls Publishing; 2018.

24. Suzuki I, Tanaka H, Kinoshita A, Oikawa S, Osawa M, Yadomae T. Effect of orally administered betaǵlucan on macrophaǵes function in mice. Int $\mathrm{J}$ Immunopharmacol 1990; 12: 675-684.

25. Fedotcheva NI, Litvinova EG, Zakharchenko MV, Khunderyakova NV, Fadeev RS, Teplova VV, Fedotcheva TA, Beloborodova NV, Kondrashova MN. Substrate-specific reduction of tetrazolium salts by isolated mitochondria, tissues, and leukocytes. Biochemistry (Mose) 2017; 82(2):192-204.

26. Moradzadeh M, Hosseini, A Rakhshandeh H, Aghae A, and Sadeghnia R H. Cuscuta campestris induces apoptosis by increasing reactive oxyǵen species generation in human leukemic cells. Avicenna J Phytomed 2018; 8(3): 237-245.

27. Kim HJ, Cho MH, Shim WH, Kim JK, Jeon EY, Kim DH, Yoon SY. Deficient autophaǵy in microglia impairs synaptic pruning and causes social behavioral defects. Mol Psychiatry 2017; 22(11):1576-1584.

28. Adams JB, Johansen LJ, Powell LD, Quig D, Rubin RA. Gastrointestinal flora and gastrointestinal status in children with autism--comparisons to typical children and correlation with autism severity. BMC Gastroenterol 2011; 11:22. 